\title{
Russian Expert and Official Geopolitical Narratives on the Arctic: Decoding Topical and Paradigmatic DNA
}

\author{
Jakub Godzimirski* \\ Norwegian Institute of International Affairs, Norway
}

\section{Alexander Sergunin \\ St Petersburg State University and Moscow State Institute of International Relations, Russia}

\begin{abstract}
This article examines current Russian expert and official narratives on the Arctic, situating them in the broader context of the debate on Russia's role in the international system. Combining a critical geopolitics approach to the study of international relations with content analysis tools, we map how structural geopolitical changes in the wider region have shaped narratives on the Arctic in Russia today. Two types of Russian narratives on the Arctic are explored-the one put forward by members of the Russian expert community, and the one that emerges from official documents and statements by members of the Russian policymaking community. With the expert narratives, we pay particular attention to the Arctic topics featured and how they are informed by various mainstream approaches to the study of international relations (IR). In examining policy practitioners' narrative approaches, we trace the overlaps and differences between these and the expert narratives. Current expert and official Russian narratives on the Arctic appear to be influenced mostly by neorealist and neoliberal ideas in IR, without substantial modifications after the 2014 conflict, thus showing relatively high ideational continuity.
\end{abstract}

Keywords: Russia; the Arctic; critical geopolitics; expert narratives; official narratives

Responsible Editor: Helge Blakkisrud, Norwegian Institute of International Affairs, Norway

Received: August 2018; Accepted: February 2020; Published: April 2020

\footnotetext{
^Correspondence to: Jakub Godzimirski, email: jmg@nupi.no

(C) 2020 Jakub Godzimirski \& Alexander Sergunin. This is an Open Access article distributed under the terms of the Creative Commons Attribution-NonCommercial 4.0 International License (https://creativecommons.org/licenses/by-nc/4.0/), allowing third parties to share their work (copy, distribute, transmit) and to adapt it, under the condition that the authors are given credit, that the work is not used for commercial purposes, and that in the event of reuse or distribution, the terms of this license are made clear.

Citation: Fakub Godzimirski \& Alexander Sergunin. "Russian Expert and Official Geopolitical Narratives on the Arctic: Decoding Topical and Paradigmatic DNA"Arctic Review on Law and Politics, Vol. 11, 2020, pp. 22-46. http://dx.doi.org/10.23865/arctic.v11.1350
} 


\section{Introduction ${ }^{1}$}

In recent years, the Arctic has been moving higher on Russia's international and national agenda. There are at least four major structural factors that can explain this. First, given the increasing role played by Arctic natural resources in Moscow's strategic designs, the region has become pivotal to Russian strategic security and economic interests, with the debate on the importance of the Northern Sea Route (NSR) among the hottest topics. Second, after a period of strategic collapse in the 1990s, Russia has strengthened its capabilities and embarked on a bolder approach in its security and foreign policy-also in the Arctic. This was signaled symbolically by the 2007 Russian flag-planting on the seabed near the North Pole by the polar explorer-cum-politician Artur Chilingarov, and militarily by Moscow resuming its air and sea patrolling of the Arctic and North Atlantic that same year, albeit at a lower level than in the Cold War era. Third, the Arctic is increasingly seen as a "retrieved" territory now that climate change has made visible impacts on geographical features of the region, and the shrinking ice cap may be creating new opportunities for development, transportation, and resource extraction. Fourth, this "re-opening" of the Arctic caused by climate change is paralleled by another structural change- the relative decline of the West and the rise of the rest of the world, with China in particular showing greater interest in the Arctic, including closer economic and security cooperation with Russia. ${ }^{2}$

These structural changes have compelled various actors, including Russia, to reformulate their understandings of the region. According to one recent study, climate change is "not only reshaping the physical geographies of the North but also its commercial, political and scientific importance." ${ }^{3}$ This makes the Arctic a unique testing ground for investigating the relationship between state policy, power structures, and geographical change.

The "retrieved" Arctic is often seen as a space where states and nations, driven by strategic considerations and economic expectations, "naturally vie for power over territory and resources" - as in Africa in the $19^{\text {th }}$ century. This trend-the "scramble for the Arctic" However, closer scrutiny of how Arctic politics actually play out shows that, even after the outbreak of the Ukraine conflict in 2014, Russia has sought to maintain cooperative relations with the other Arctic actors-all of whom represent the West.

Drawing on a critical geopolitics approach, we 1) map key topical and paradigmatic concepts in Russian expert and official narratives on the Arctic through quantitative and qualitative examination of a set of Russian statements on the Arctic; 2) examine conceptual tensions within Russian expert and official Arctic policy narratives prior to and after the 2014 crisis; 3 ) gauge possible impacts of this crisis on how the Arctic is presented in these narratives. Whereas classical geopolitics focuses on how geography can influence politics, critical geopolitics aims to show "how geographical claims and assumptions function in political debates and political practice." ${ }^{\prime 7}$ In this 
perspective, politics and geography should be seen "as produced through the representational, cultural and interpretive practices of geopolitics, which in themselves were understood as reproducing hegemonic power relations."

We begin by examining formal geopolitical approaches towards the Arctic, and then turn to practical geopolitics. By "formal geopolitics" we mean how various understandings of the geopolitical forces and frameworks that shape international relations inform Russian expert thinking about the Arctic. "Practical geopolitics" is "concerned with the geographical politics involved in everyday practice of foreign policy," and how "common geographical understandings and perceptions enframe foreign policy conceptualization and decision-making." 10 We examine how academics, politicians, and government officials present the Arctic in their statements, and what these representations of the Arctic may say about Russian Arctic priorities and understandings of and approaches to international relations-regionally and globally. ${ }^{11}$

We offer an examination of the "topical and paradigmatic DNA" found in Russian expert and official statements on the Arctic. Russian debate on the Arctic does not take place in a conceptual vacuum, so we seek to identify which Arctic topics are deemed most important and which "paradigmatic genes"-understood here as basic ideas on the nature of international relations rooted in various paradigmatic approaches - can be found in these statements. A "real" DNA analysis requires only a small sample of cells to be able to reconstruct the genetic makeup of the whole individual. Similarly, we take a sample of representative Russian expert and official statements on the Arctic to identify what the key Arctic topics are and which key concepts can be traced in these statements. Such a "topical and paradigmatic DNA analysis" will show what ideas inform Russian expert and official "talk" on the Arctic; the actual "walk" - real-life policies in the Arctic - is covered by another article in this thematic cluster. ${ }^{12}$

In section 2, we explore how geopolitical traditions discernible in today's Russia inform expert narratives on the "retrieved" Arctic. In section 3, we turn to official geopolitical approaches, examining how questions concerning the Arctic have been dealt with in Russian official statements on foreign and security policy. In section 4, we discuss to what extent expert narratives on the Arctic appear to have influenced the Arctic narratives of Russia's policymakers before and after the 2014 crisis. Finally, we offer some conclusions on the evolution of these narratives and how they are reflected in actual Russian policymaking in the Arctic.

\section{Russian expert narratives on the Arctic}

How do Russian experts see the role of the Arctic in Russian strategic designs? How is their thinking informed by their understanding of the nature of international relations and key issues facing Russia in the Arctic? How is their understanding of international relations influenced by ongoing international academic debates on the forces and ideas that shape international relations? ${ }^{\text {13 }}$ 
We have conducted a quantitative examination of 49 expert articles on various aspects of Arctic policy published before 2013 and republished in 2013 by the Russian International Affairs Council (RIAC) ${ }^{14}$ As our focus is on international aspects of Russian Arctic policy, and RIAC is recognized as a major Russian arena for the exchange of views on Russian foreign policy, we treat this collection as a representative body of Russian expert statements on the Arctic - and of Russian academic debate on the Arctic. Although it could be argued that RIAC, which receives 50 percent of its funding from the Russian state, could present a biased sample in its anthology, the organization "appears to be relatively independent when taking part in public debate." 15

The 49 articles are used for two purposes. First, to identify what topics dominated Russian expert debate on the Arctic prior to the 2014 crisis. Second, to examine what key Arctic issues (what elements of the "topical DNA") and what paradigmatic understandings of the nature of international relations ("paradigmatic DNA") dominated this debate.

To address the first issue, we undertook a quantitative and a qualitative examination of the articles to identify which broader topics were addressed, and by whom (Table 1).

Table 1. Topics in the Russian Arctic expert debate

\begin{tabular}{|c|c|}
\hline Topic & Russian experts addressing this topic in the RIAC volume \\
\hline Law, legal aspects & A. Kovalev, A. Vylegzhanin \\
\hline Arctic governance & A. Cherepovitsin, A. Fadeev, F. Larichkin \\
\hline Natural resources & S. Afontsev, M. Morgunova, A. Tsyunevskii \\
\hline Economy & N. Babich, E. Bashmakova, M. Kashka, V. Ruksha, V. Selin, A. Smirnov \\
\hline Energy resources & V. Bogoyavlenskii, A. Cherepovitsin, A. Fadeev, F. Larichkin \\
\hline Ecology & V. Dmitriev, A. Fadeev, A. Solovyanov, A. Svechnikov \\
\hline Climate change & $\begin{array}{l}\text { G. Alekseev, Ye. Aleksandrov, N. Ivanov, N. Kharlanenkova, Y. Kattsov, B. Porfiriev, } \\
\text { V. Radionov }\end{array}$ \\
\hline $\begin{array}{l}\text { International } \\
\text { relations }\end{array}$ & $\begin{array}{l}\text { A. Fadeev, A. Fenenko, V. Karlusov, A. Khramchikhin, V. Konyshev, V. Koptelov, } \\
\text { Ye. Kudryashova, S. Lunev, M. Morgunova, A. Oreshenkov, S. Oznobishchev, } \\
\text { M. Rykthik, A. Sergunin, V. Stepanova, D. Tulupov, S. Utkin, A. Vasiliev }\end{array}$ \\
\hline Security & $\begin{array}{l}\text { A. Khramchikhin, V. Konyshev, Yu. Rubinskii, A. Sergunin, E. Studneva, E. Telegina, } \\
\text { I. Veselov, A. Zagorskii }\end{array}$ \\
\hline Cooperation & V. Dmitriev, Ye. Kudryashova, A. Oreshenkov, V. Stepanova, A. Vasiliev \\
\hline Military aspects & A. Khramchikhin, V. Konyshev, S. Oznobishchev, A. Sergunin, A. Zagorskii \\
\hline Transport & M. Kortunova, A. Nikolaeva, V. Selin \\
\hline Research, science & $\begin{array}{l}\text { I. Ashik, G. Baskakov, S. Dzhenyuk, I. Frolov, S. Kirillov, A. Makosko, G. Matishov, } \\
\text { A. Nekipelov, A. Pilyasov }\end{array}$ \\
\hline Infrastructure & N. Babich, M. Kashka, M. Kortunova, V. Ruksha, A. Smirnov \\
\hline Shipping & N. Babich, M. Kashka, M. Kortunova, A. Nikolaeva, V. Ruksha, A. Smirnov \\
\hline Maritime & $\begin{array}{l}\text { I. Ashik, N. Babich, G. Baskakov, I. Frolov, M. Kashka, S. Kirillov, M. Kortunova, } \\
\text { A. Nikolaeva, V. Ruksha, S. Selin, A. Smirnov }\end{array}$ \\
\hline Strategic aspects & $\begin{array}{l}\text { A. Abramov, V. Dvorkin, A. Khramchikhin, V. Konyshev, S. Oznobishchev, Yu. } \\
\text { Rubinskii, M. Rykthik, A. Sergunin, I. Veselov, L. Voronkov, K. Voronov, A. Zagorskii }\end{array}$ \\
\hline
\end{tabular}


The second issue-identifying which Arctic issues Russian experts focused on and which paradigmatic approaches dominated Russian Arctic expert debate prior to the 2014 crisis-involved several steps. First, we prepared a list of relevant words/ concepts, to map what issues were central in the expert debate as represented in the 2013 RIAC anthology. Next, we assumed that these words/concepts were representative of various paradigmatic approaches to international relations. ${ }^{16}$ For example, we assumed that concepts related to state activities, power, threats, challenges, conflict, military issues, deterrence, and competition were representative of various realist approaches. Further, concepts focusing on cooperation, legal issues, opportunities, interactions, economic aspects, and norms were categorized as representative of liberalinstitutionalist approaches; and concepts related to identity, norms, and values as typical of constructivist approaches. Based on this list, we conducted a quantitative analysis to identify the elements of "topical and paradigmatic DNA" represented in this body of Russian expert debate on the Arctic (Table 2).

Table 2. "Topical and paradigmatic DNA" in RIAC expert debate on the Arctic

\begin{tabular}{|c|c|c|}
\hline $\begin{array}{l}\text { Key issues } \\
\text { ("topical DNA") }\end{array}$ & $\begin{array}{c}\text { Paradigmatic approaches } \\
\text { ("paradigmatic DNA") } \\
\text { ( } \mathbf{R}=\text { realism, } \mathbf{L}=\text { liberalism } \\
\mathbf{C}=\text { constructivism })\end{array}$ & $\begin{array}{c}\text { Number of occurrences } \\
(\text { Total 208,767) }\end{array}$ \\
\hline Международ (Internation`) & $\mathrm{L} / \mathrm{R}$ & 766 \\
\hline Государст ${ }^{\star}\left(\right.$ State $\left.^{\star}\right)$ & $\mathrm{R}$ & 748 \\
\hline Pecypc $^{\star}\left(\right.$ Resourc $\left.^{\star}\right)$ & $\mathrm{L}$ & 737 \\
\hline $\operatorname{He}_{T^{\star}}\left(\mathrm{Oil}^{\star}\right)$ & $\mathrm{L}$ & 696 \\
\hline Развит ${ }^{\star}\left(\right.$ Develop $\left.{ }^{\star}\right)$ & $\mathrm{L}$ & 551 \\
\hline Сотруднич ${ }^{\star}\left(\right.$ Cooperat $\left.{ }^{\star}\right)$ & $\mathrm{L}$ & 535 \\
\hline 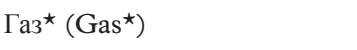 & $\mathrm{L}$ & 531 \\
\hline Эконом^ (Econom $\left.^{\star}\right)$ & $\mathrm{L}$ & 528 \\
\hline Военн $^{\star}\left(\right.$ Militar $\left.^{\star}\right)$ & $\mathrm{R}$ & 453 \\
\hline Клима ${ }^{\star}\left(\right.$ Climat $\left.^{\star}\right)$ & $\mathrm{L}$ & 430 \\
\hline Освоен $^{\star}\left(\operatorname{Reclam}^{\star}\right)$ & $\mathrm{L}$ & 398 \\
\hline Безопас ${ }^{\star}\left(\right.$ Securit $\left.^{\star}\right)$ & $\mathrm{R}$ & 363 \\
\hline Право $\left(\mathrm{Leg}^{\star}\right)$ & $\mathrm{L}$ & 255 \\
\hline Углево ${ }^{\star}$ (Hydrocarb夫) & $\mathrm{L}$ & 201 \\
\hline Возможнос (Possibili $\left.^{\star}\right)$ & $\mathrm{L}$ & 187 \\
\hline Закон ${ }^{\star}\left(\mathrm{Law}^{\star}\right)$ & $\mathrm{L}$ & 176 \\
\hline Поддерж^ (Support) & $\mathrm{L}$ & 137 \\
\hline Институ $($ Institu^) & $\mathrm{L}$ & 133 \\
\hline Инфрастр夫 (Infrastruct $\left.{ }^{\star}\right)$ & $\mathrm{L}$ & 128 \\
\hline Противо ${ }^{\star}\left(\right.$ Contr $\left.^{\star}\right)$ & $\mathrm{R}$ & 116 \\
\hline Взаимод (Interact $\left.^{\star}\right)$ & $\mathrm{L}$ & 107 \\
\hline Hopм $^{\star}$ (Norm) & $\mathrm{L} / \mathrm{C}$ & 105 \\
\hline
\end{tabular}


Table 2. (Continued)

\begin{tabular}{|c|c|c|}
\hline $\begin{array}{l}\text { Key issues } \\
\text { ("topical DNA") }\end{array}$ & $\begin{array}{c}\text { Paradigmatic approaches } \\
\text { ("paradigmatic DNA") } \\
\text { ( } \mathbf{R}=\text { realism, } \mathbf{L}=\text { liberalism, } \\
\mathbf{C}=\text { constructivism) }\end{array}$ & $\begin{array}{c}\text { Number of occurrences } \\
\quad(\text { Total 208,767) }\end{array}$ \\
\hline Конфликт ${ }^{\star}\left(\right.$ Conflict $\left.{ }^{\star}\right)$ & $\mathrm{R}$ & 91 \\
\hline 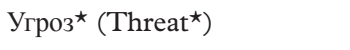 & $\mathrm{R}$ & 90 \\
\hline Вооруж$^{\star}\left(\operatorname{Arm}^{\star}\right)$ & $\mathrm{R}$ & 84 \\
\hline Суверен $^{\star}($ Sovereign $\star)$ & $\mathrm{R}$ & 83 \\
\hline Боев ${ }^{\star}\left(\mathrm{Comba}^{\star}\right)$ & $\mathrm{R}$ & 72 \\
\hline Конкур (Compet $\left.^{\star}\right)$ & $\mathrm{R} / \mathrm{L}$ & 72 \\
\hline Борьб^ $\left(\right.$ Fight $\left.^{\star}\right)$ & $\mathrm{R}$ & 65 \\
\hline Войнћ (War^) & $\mathrm{R}$ & 61 \\
\hline Вызов ${ }^{\star}\left(\right.$ Challeng $\left.{ }^{\star}\right)$ & $\mathrm{R}$ & 45 \\
\hline Геополит ${ }^{\star}\left(\right.$ Geopolitic $\left.^{\star}\right)$ & $\mathrm{R}$ & 39 \\
\hline Многосто^ ${ }^{\star}$ Multila*) & $\mathrm{L}$ & 39 \\
\hline Кризис ${ }^{\star}\left(\right.$ Crisis $\left.^{\star}\right)$ & $\mathrm{R}$ & 28 \\
\hline Сдержив ${ }^{\star}\left(\right.$ Deter $\left.^{\star}\right)$ & $\mathrm{R}$ & 27 \\
\hline Соблю ${ }^{\star}\left(\mathrm{Observ}^{\star}\right)$ & $\mathrm{L}$ & 24 \\
\hline Гонк` Race $\left.^{\star}\right)$ & $\mathrm{R}$ & 17 \\
\hline 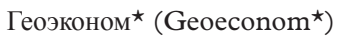 & $\mathrm{L}$ & 15 \\
\hline Незакон $^{\star}\left(\right.$ Illegal $\left.{ }^{\star}\right)$ & $\mathrm{R} / \mathrm{L}$ & 12 \\
\hline Столкн ${ }^{\star}\left(\mathrm{Clash}^{\star}\right)$ & $\mathrm{R}$ & 13 \\
\hline Напряж^ (Tension`) & $\mathrm{R}$ & 11 \\
\hline Противни ${ }^{\star}\left(\right.$ Enem $\left.^{\star}\right)$ & $\mathrm{R}$ & 9 \\
\hline Ценност^ (Value $\left.^{\star}\right)$ & $\mathrm{C} / \mathrm{L}$ & 8 \\
\hline Идентич ${ }^{\star}\left(\right.$ Identi $\left.{ }^{\star}\right)$ & $\mathrm{C}$ & 2 \\
\hline Либерал ${ }^{\star}\left(\right.$ Liberal$\left.^{\star}\right)$ & $\mathrm{L}$ & 3 \\
\hline Сопротивл ${ }^{\star}\left(\mathrm{Oppos}^{\star}\right)$ & $\mathrm{R}$ & 1 \\
\hline
\end{tabular}

We can draw two conclusions from this quantitative analysis. First, it seems that Russian experts were by 2013 deeply interested in international aspects of Arctic cooperation, paid serious attention to the role of states in the process of shaping Arctic policy, and focused mainly on economic aspects of cooperation, although security-related questions were also fairly high on their agenda. Second, the pre2014 Russian debate on the Arctic was heavily informed by understandings of international relations rooted in two mainstream IR approaches: "realist" vocabulary accounted for 26.4 percent (2428/9192) and "liberal-institutionalist" for 63.2 percent $(5811 / 9192)$ of all hits in the examined body of texts. Only 0.02 percent (2/91929) was unequivocally related to a constructivist approach, with the remainder representing mixed "paradigmatic DNA." 
In the following, we use the results of this examination of the content of the 49 expert articles as a benchmark for measuring overlaps and differences between expert and official Arctic statements. First, however, we briefly turn to how the three strands of IR have been conceptualized and discussed in Russian expert narratives on the Arctic.

\subsection{The rationalist strand}

\subsubsection{Neorealism —or states, power and conflict potential}

The neorealist approach to IR sees states as the key actors. In forging their Arctic strategies, Russian neorealists have preferred Kenneth Waltz's interpretation of sovereignty, which is based on the assumption that a state is sovereign when "it decides for itself how it will cope with its internal and external problems, including whether or not to seek assistance from others and in doing so to limit its freedom by making commitments to them." ${ }^{\prime 17}$

This approach sees states as the sole legitimate force of national power within their own borders. The same applies to world politics, where states act as sovereign and (theoretically) equal international actors and remain the main subjects of international law. According to John Mearsheimer, the international relations system "comprises independent states that have no central authority over them. Sovereignty, in other words, inheres in states because there is no higher ruling body in the international system. There is no 'government over governments."' 18

The Russian neorealist vision of the Arctic is based on the following understandings:

- national interests are central, hereunder economic and strategic interests; $;^{19}$

- preservation of Russian sovereignty over the Arctic territories, natural resources, and maritime routes is of major concern; ${ }^{20}$

- international law is mainly an instrument for resisting foreign "encroachments" on Russia's sovereign rights, and maintaining control over its Arctic spaces/ resources/transport/communications; ${ }^{21}$

- a regional governance regime is possible only as a temporary compromise among the five (coastal) Arctic powers-Canada, Denmark, Norway, Russia, and the USA. ${ }^{22}$

Neorealists have a pragmatic approach to international institutions like the UN, the Arctic Council (AC), and the Barents Euro-Arctic Council (BEAC), generally belittling their role in a system where power is seen as the dominant factor and sovereign states as the main actors. Preference is given to using these bodies to protect Russia's national interests in the region, rather than seeking to implement more abstract universal/cosmopolitan values. ${ }^{23}$

Russian neorealists tend to view every Arctic problem through the lens of security, especially in the aftermath of the 2014 conflict. The radical branch of the Russian neorealist school sees the Arctic as an area in the crosshairs of the perennial 
geopolitical rivalry between Russia and the West. ${ }^{24}$ These scholars believe that today, unlike in the past, the West prefers using economic rather than military instruments in order to put pressure on Russia. However, they also hold, the aim of Western policies remains expansionist: basically, this means assigning to Russia the status of "younger partner" to the West-a source of cheap natural resources and labor, and a market for its products. Perceptions of the USA and NATO as main security threats are still alive in large parts of the Russian expert establishment, and military and diplomatic activities undertaken by the USA and NATO in the Arctic are often interpreted as "offensive." ${ }^{25}$

\subsubsection{Liberal-institutionalism —institutions, interdependencies, globalization, and cooperation}

As noted, the liberal-institutionalist approach seems to have dominated Russian expert debate prior to the 2014 crisis and is still traceable in many recent studies. ${ }^{26}$ In contrast to neorealism, this approach represents a radical departure from the Soviet-era Marxist-Leninist foreign policy doctrine. According to the neoliberals, territorial sovereignty as the ordering principle for world politics has been redefined, and partly transcended, by networks of interaction that involve actors of many different kinds and at different levels, including the global level. Although the state is often a player in these networks, it does not necessarily control them, and is increasingly intertwined with them. ${ }^{27}$

The neoliberal approach sees the Arctic (especially its natural resources, primary energy resources, and sea routes) as a common heritage, asset, and responsibility entrusted to humankind, ${ }^{28}$ to be cautiously developed jointly with other countries. ${ }^{29}$ International law should regulate Arctic politics and guide institutions and the emerging regional governance regime. Viewing subregional institutions like the AC and BEAC as parts of the global and regional governance systems, the neoliberals hold that these should be designed and should function accordingly. The AC and BEAC should avoid discussing security issues: main priorities should be environmental issues and the "human dimension" (indigenous peoples, and Arctic residents in general).

According to the neoliberals, the Russian North has lost its military significance in the post-Cold War era and should no longer be viewed as a Russian military outpost. They hope that the region will be opened up for further international cooperation, as a "gateway" region that could help Russia integrate into European and international multilateral institutions. Thus, priority should be given not to the most divisive issues, but to common interests that need to be addressed jointly-like trade, cross-border cooperation, transport, environment, healthcare, Arctic research, indigenous affairs, people-to-people contacts, and better welfare for Arctic communities. The various programs launched by regional organizations are seen as playing positive and important roles in the development of Arctic cooperation. ${ }^{30}$ 
Further, according to the neoliberals, all security-related questions and conflicts should be resolved through negotiations, compromise, and a deeper understanding of the positions of the parties involved. They stress the importance of developing a system of confidence- and security-building measures to improve the regional environment and increase mutual trust. ${ }^{31}$

In their interaction, Arctic actors should be guided by the aims of:

- preserving peace, predictability and stability in the Arctic region;

- ensuring the sustainable management and development of natural resources;

- promoting international cooperation to meet common challenges in the Arctic;

- developing national and international legal mechanisms to promote more efficient Arctic governance. ${ }^{32}$

Neoliberal thinking about Russia's role in the Arctic is heavily influenced by the processes of globalization. As "globalization is characterized by a proliferation in the number of and kinds of agents that are pertinent to the making of foreign policy," ${ }^{33}$ this has had consequences for how Russian neoliberal experts view the Arctic. They argue that globalization and regionalization are worldwide processes that Russia cannot avoid: indeed, the Arctic should be a place where these two trends can intertwine. Thus, Moscow should not relegate sovereignty-related issues to a purely regional agenda, but instead internalize cooperative and cosmopolitan concepts and ideas. ${ }^{34}$

The most radical globalists hold that an international legal regime similar to that under the Antarctic Treaty should be established in the Arctic, to make it a "region of peace and cooperation." ${ }^{35}$ Under this proposed new Arctic regime, all economic and military activities in the region should be prohibited, and only the subsistence economies of the indigenous peoples of the North and research activities should be allowed. Some globalists even propose the establishment of a UN-based governance regime in the Arctic, to replace the current national sovereignty-oriented model. ${ }^{36}$

\subsubsection{Rationalist in-betweens}

Between the two apparent extremes-neorealism and neoliberalism-there are numerous other schools of Russian academics/experts that converge around certain common positions and principles as regards the existing and emerging legal system regulating cooperation in the Arctic. These more moderate "rationalist in-betweens" argue that Russia should act as a responsible international actor in line with international law and commitments. International conventions and declarations such as the UN Convention on the Law of the Sea (UNCLOS); the Ilulissat Declaration (2008); the AC-sponsored agreements on search and rescue operations (2011), on oil-spill response (2013), and on Arctic science cooperation (2017); and the International Maritime Organization (IMO) Polar Code should constitute the legal basis for Russia's Arctic strategy. ${ }^{37}$ Although these experts do not believe that the international 
institutions engaged in Arctic affairs will be able to exercise real supranational governance there in the foreseeable future, they hold that some institutional reforms are possible, for instance transforming the Arctic Council from a discussion forum to a fully-fledged intergovernmental international organization. ${ }^{38}$ However, they also argue that Russia should stand firm in defending its legitimate rights and national interests in the region -including: establishing the outer limits of the Russian continental shelf in the Arctic Ocean, maintaining control over maritime routes, combatting poaching and smuggling in the Arctic Zone of the Russian Federation (AZRF), and continuing to modernize armed forces deployed in the High North.

Adherents of such intermediary positions seem to favor the creation of a flexible regional governance system in the Arctic based on a pragmatic combination of hard and soft law. They are even open to the establishment of some elements of supranational governance in the region, albeit only in areas currently beyond national jurisdiction and where any economic activity - whether extraction of hydrocarbons or fisheries-is currently impossible due to the extremely fragile environment and harsh climate.

In summary: regardless of the strong polarization of the neorealist-neoliberal dichotomy, Russian mainstream expert thinking on Arctic policy has been heavily influenced by those experts who seek to combine neorealist and neoliberal elements in advocating a more cooperative approach to the Arctic-taking into account national-security sensitivities evident in growing tensions in the aftermath of the 2014 crisis. ${ }^{39}$ Such realist-liberal convergence is not solely a Russian phenomenonalready in 1997 Ole Wæver noted this neo-realist and neo-liberal synthesis as a characteristic feature in the ongoing academic debate on ideas guiding thinking about international relations. ${ }^{40}$

\subsection{The post-positivist strand}

\subsubsection{Constructivism, or identity, values and norms}

While weakly represented in the RIAC anthology examined for this study, constructivist approaches to the Arctic also deserve attention. Constructivists view Arctic issues mainly through the prism of identity: as identity is undergoing constant changes, this should also be reflected in approaches to the Arctic, they hold. For instance, older ways of talking and thinking about the Arctic, like "conquering the North," and "struggling with the forces of nature," should be replaced by other narratives. The Arctic should not be seen solely as Russia's "strategic resource base"-it should be turned into a "region of peace and cooperation."

Constructivists worry about the persistence of imperialist, nationalist, and alarmist discourses, periodically reproduced in post-Soviet Russia over the past quartercentury. ${ }^{42}$ The continuation of confrontational stereotypes is seen as a serious obstacle to the development of a more cooperative approach in the Arctic. Constructivists argue that Russia's interests there should be redefined, and not focused on economic 
exploitation or the use of the territory as a military outpost in confrontational foreign policy, but on the environmental sustainability of the region. ${ }^{43}$

Central to the constructivist understanding are ideas about perceptions, status, and recognition as important drivers of foreign and security policy. From a constructivist perspective, Russia's growing military presence in the Arctic could be viewed as serving highly symbolic purposes: it could have more to do with Russia signaling a desire to be recognized as a major regional and global power than with the actual security situation in the region. ${ }^{44}$

\section{The official geopolitical Arctic narrative}

Gearóid Ó Tuathail has argued that practical geopolitical reasoning is used by policymakers "whenever they try to make spatial sense of the world, implicitly utilizing inherited forms of geographical knowledge to enframe particular questions and tacitly deploying cultural geographic discourses to explain certain dramas and events." 45 In the following, we try to reconstruct how the Arctic has been dealt with in the Russian official strategic narrative. Here we focus on current official documents of doctrinal character, with some historical excursions to illustrate the evolution of official geopolitical narratives on the Arctic.

From the collapse of the Soviet Union and up until the early 2000s, the Kremlin paid scant attention to the Arctic. With the end of the Cold War, the region lost its military-strategic significance for Moscow as an arena of possible confrontation with NATO/the USA $;{ }^{46}$ during the Yeltsin era, the region's economic potential was underestimated and the state's ability to provide funding for projects in the Arctic limited. The federal government saw the Arctic as a burden-a region beset with socioeconomic problems created by unrealistic Soviet plans that needed to be addressed, at a time when the whole country had to deal with deep political, social, and economic crises. ${ }^{47}$ All but abandoned by Moscow, the Arctic regions were left to their own devices. ${ }^{48}$

Then things started to change. First, climate change gave indications that the Arctic was becoming more readily accessible, which led various actors, including Russia, to view it with renewed interest. Second, as the general socioeconomic situation in Russia improved, the Putin administration launched an ambitious agenda for national revival, with a greater focus on the Arctic. In June 2001, the government approved the draft of "The Foundations of the State Policy of the Russian Federation in the Arctic," ${ }^{49}$ listing Russia's national interests and main strategies in the Arctic.

However, it took seven years (and another president) to develop a more comprehensive Arctic policy document. In September 2008, President Dmitrii Medvedev approved "The Foundations of the State Policy of the Russian Federation in the Arctic through 2020 and beyond." ${ }^{50}$ The exploitation of Arctic natural resources, the development of the Northern Sea Route (NSR) as a unified national 
transport corridor and line of communications, and maintaining the region as a zone of peace and international cooperation were listed as issues of key economic importance.

In the security field, the main goals were "to maintain the necessary combat potential of general-purpose troops (forces)," and to strengthen the Coast Guard, border control, and technical control over straits and river estuaries along the entire NSR. The Arctic Group of Forces was to be responsible not only for territorial defense, but also for protecting Russian economic interests in the region. In addition, the Northern Fleet, seen as an important instrument for demonstrating Russia's sovereign rights in the High North, was to be modernized. "The National Security Strategy of the Russian Federation through 2020," released in May 2009, stressed the competition for new energy resources-resources crucial to the revival of Russia as a great power-and identified the Arctic as a main arena for potential future conflict. ${ }^{51}$

In 2013, Russia saw the development of its first post-Soviet Arctic strategy. In February that year, President Putin approved "The Strategy for the Development of the Arctic Zone of the Russian Federation and Ensuring National Security for the Period through 2020." 52 According to its preamble, this Strategy is both a follow-up and a revision of the 2008 document, intended to provide a conceptual basis for sustainable development of the AZRF.

According to the 2013 Strategy, Russia should be open to international cooperation to solve various Arctic challenges and ensure the sustainable development of the region as a whole. At the same time, the strategy stresses Russia's national sovereignty over the NSR and calls for measures to protect Russian national interests in the region. It highlights the need for the Russian armed forces to be able to meet military dangers and threats to national security in the region, protect Russian interests in the exclusive economic zone (EEZ), and deter potential aggression. ${ }^{53}$

In April 2014, the government approved a state program on "Socio-Economic Development of the Arctic Zone of the Russian Federation for the Period through 2020 " which aimed to concretize the 2013 Strategy and implement various projects in the AZRF. ${ }^{54}$ An updated version of the program (approved in August 2017) was extended until 2025. ${ }^{55}$

The 2013 Arctic Strategy remains in force, but after the outbreak of the conflict in Ukraine, Russian authorities have revised the whole set of strategic doctrines, starting with the military doctrine in December $2014 .{ }^{56}$ Here the Arctic is mentioned only once-as an area where Russia's national interests will be protected by the armed forces.

In July 2015, Putin approved a new version of the maritime doctrine. ${ }^{57}$ This identifies the Arctic, along with the North Atlantic, as regions where NATO activities and international competition for natural resources and sea routes continue to grow. According to the doctrine, Russia's naval forces and nuclear icebreaker fleet must be modernized by 2020 - a call that has resulted in the launch of a series of powerful 
nuclear icebreakers ${ }^{58}$ and the Russian Navy receiving its first new diesel-electric icebreaker in 40 years. ${ }^{59}$

Later that year, Putin signed a new national security strategy. ${ }^{60}$ Here the Arctic is mentioned three times: as an area where international competition over offshore natural resources might increase; as an important transport/communication corridor crucial to Russian economic security; and finally, as a region of international cooperation, peace, and stability.

In November 2016, a new version of the "Foreign Policy Concept of the Russian Federation" ${ }^{61}$ entered into force. Here the Arctic is mentioned nine times: once as a region for potential cooperation with Canada, and eight times in a section focusing on the Arctic as an arena for mutually advantageous cooperation with other actors. The Concept stresses the importance of regional cooperation in areas such as sustainable development of natural resources, expansion of transport infrastructure (including the NSR), environmental protection, and the preservation of peace and stability. Also emphasized in the Concept is the need to strengthen regional multilateral institutions like the AC and BEAC. Above all, the document stresses the importance of preventing military confrontation in the region, declaring that cooperation in the Arctic should be shielded from the tension between Russia and the West caused by the conflict in Ukraine.

In July 2017, President Putin approved "The Foundations of the State Policy on Naval Activities through 2030,"62 operationalizing the 2015 Maritime Doctrine. Here the Arctic is highlighted as an area where multiple states, primarily the USA and its allies, are striving to secure dominance and achieve naval superiority; as an area of potential confrontation due to attempts by certain countries to control the hydrocarbon resources of the Arctic; and as an area where Russia should develop dual-use infrastructure serving both commercial and civilian vessels as well as those of the Navy and Coast Guard.

Although this new set of strategic documents aims to reflect changes in Russian thinking on emergent challenges in Russia's relations with the outside world-and especially with the West after the 2014 crisis, questions related to the Arctic continue to be discussed in essentially the same manner as in the previous set of doctrines, with no dramatic changes in Russian official understandings of the Arctic discernible. This may reflect continuity in Russian approaches towards the Arctic as well as an interest in letting Arctic cooperation, which provides Russia with an opportunity to test new policy ideas, remain unaffected by the growing tensions in Moscow's relations with the remaining Arctic powers. This continuity is especially evident if we compare the wording on the Arctic in the 2009 and 2016 versions of the Russian foreign policy concepts. In the most recent military doctrine, a new tone is evident, reflecting a greater focus on military aspects of the Arctic, but the change is hardly dramatic. While the 2010 version contains no mention of the Arctic, the 2014 variant mentions the Arctic once, as an area to be protected by the Russian military. 


\section{Travelling ideas: from expert to official geopolitical narratives}

To what extent do the official narratives on the Arctic presented in the documents we examined reflect the narratives promoted by the Russian expert community? The opaqueness of Russian policy-formulation makes it difficult to map whether and how ideas have travelled from the expert community to the policymaking community. However, by examining public statements on the Arctic, we can map whether topical foci overlap.

(Neo)realist and (neo)liberal ideas have clearly influenced the official Russian Arctic narratives. On the one hand, the official narrative presents the Arctic as a place where Russia must be prepared to face actors that may challenge its control and sovereignty. On the other hand, these official narratives reflect neoliberal ideas about soft-power instruments and an institutionalist approach to Arctic challenges. The emerging Russian Arctic policy consensus holds that the Arctic cooperative agenda should include issues like climate-change mitigation, environmental protection, response to emergency situations, air and maritime safety, search and rescue operations, Arctic research, indigenous peoples, and cross- and trans-border cooperative projects. ${ }^{63}$ Moreover, to avoid unnecessary misunderstandings and potential conflicts, many policymakers have followed the neoliberals in their call to give a greater role to existing regional and global institutions like the AC, BEAC, IMO, UNEP, and UNDP as platforms where national interests in the Arctic can be discussed and mediated. However, neoliberal visions of the currently "unclaimed" Arctic - the territories beyond the Exclusive Economic Zones-as a common asset and responsibility of humankind enjoy limited traction in Russian policymaking circles. The Kremlin's understanding of Russia's economic and strategic interests in the region makes this a no-go option today. ${ }^{64}$

Within the neorealist-neoliberal dichotomy, the Arctic can be read either as an area of potential interstate conflict or of mutually advantageous cooperation involving a range of actors. While a neorealist reading remains dominant in Russian foreign policy in general ${ }^{65}$ expert and official narratives on the Arctic are open to other interpretations and solutions - some of them rooted in a more cooperative approach. ${ }^{66}$ The official narrative has strong realist elements, presenting the Arctic as a place where Russia may be challenged by other actors: Russia must increase its military presence in the region and the capacities of its armed forces to operate under harsh climatic conditions. However, these same harsh Arctic conditions have prompted Russian policymakers to call for a more cooperative attitude towards interaction in the Arctic - an approach rooted in the liberal strand. By positioning Russia as a neorealist player open to more cooperation in the Arctic, policymakers signal Russia's increased self-confidence: Russia is to be treated as a great power to be reckoned with, also in the Arctic. Hence, policy instruments from "neorealist" and "neoliberal" inventories are used to further Russia's purely "constructivist" interest in being recognized as a great power by other actors operating in the Arctic. 
From our reading of the doctrines it seems reasonable to conclude that it is the "rationalist in-betweens," representatives of the "eclectic" schools who pragmatically combine elements from both neorealist and neoliberal thinking in their writings, who have had the greatest influence on official Russian narrative approaches to the Arctic. To explore this, we returned to the list of topics developed in connection with the examination of expert approaches in the RIAC anthology, and compared how the word frequencies identified there (the "topical and paradigmatic DNA" of the expert narrative) compare with three examples of the official narrative:

1. The 2013 Strategy for the Development of the Arctic Zone of the Russian Federation;

2. President Vladimir Putin's address to the 2019 International Arctic Forum in St Petersburg; ${ }^{67}$

3. Minister of Foreign Affairs Sergei Lavrov's speech at the 2019 Arctic Council Ministerial Meeting in Rovaniemi. ${ }^{68}$

First, we examine the overlap between pre-2014 expert and official narratives by comparing the 2013 RIAC anthology and the Arctic Strategy adopted that same year. We use the results of our examination of the 2013 RIAC anthology as a benchmark against which we measure the topical and paradigmatic overlaps between these two "Arctic statements." The results are presented in Figure 1. All terms with a difference in frequency higher than 0 indicate that the 2013 Arctic Strategy had more focus on these topics than the 2013 RIAC anthology; all terms with a difference in frequency lower than 0 indicate that the 2013 Arctic Strategy had less focus on these topics. Figure 1 shows that the 2013 Arctic Strategy pays far more attention to questions related to development, state activity, security, economy, and infrastructure than the 2013 RIAC anthology, whereas the latter pays more attention to Russia's Arctic oil and gas resources.

Second, to map continuity and change across the 2014 crisis, we carried out two analyses. First, we compare the pre-2014 expert narrative with the post-2014 official narrative: we compare word frequencies from the 2013 RIAC anthology with usage of the same terms in the two above-mentioned Arctic speeches by Putin and Lavrov. (See Figures 2 and 3.) Next, we compare changes within the official narrative preand post-2014 by repeating the same analysis, now comparing the 2013 Arctic Strategy with the 2019 Arctic speeches by Putin and Lavrov. (See Figures 4 and 5.)

Several conclusions emerge from this comparative analysis. Despite the diversity of opinions evident, we find a clear tendency towards a sort of Arctic consensus, with broad agreement on the growing significance of the Arctic, for Russia, and for the world at large. There is also agreement that Russia must devise and implement a coherent, sound Arctic strategy that identifies and addresses national interests and policy priorities in the region, including opportunities for and limits to international cooperation. 


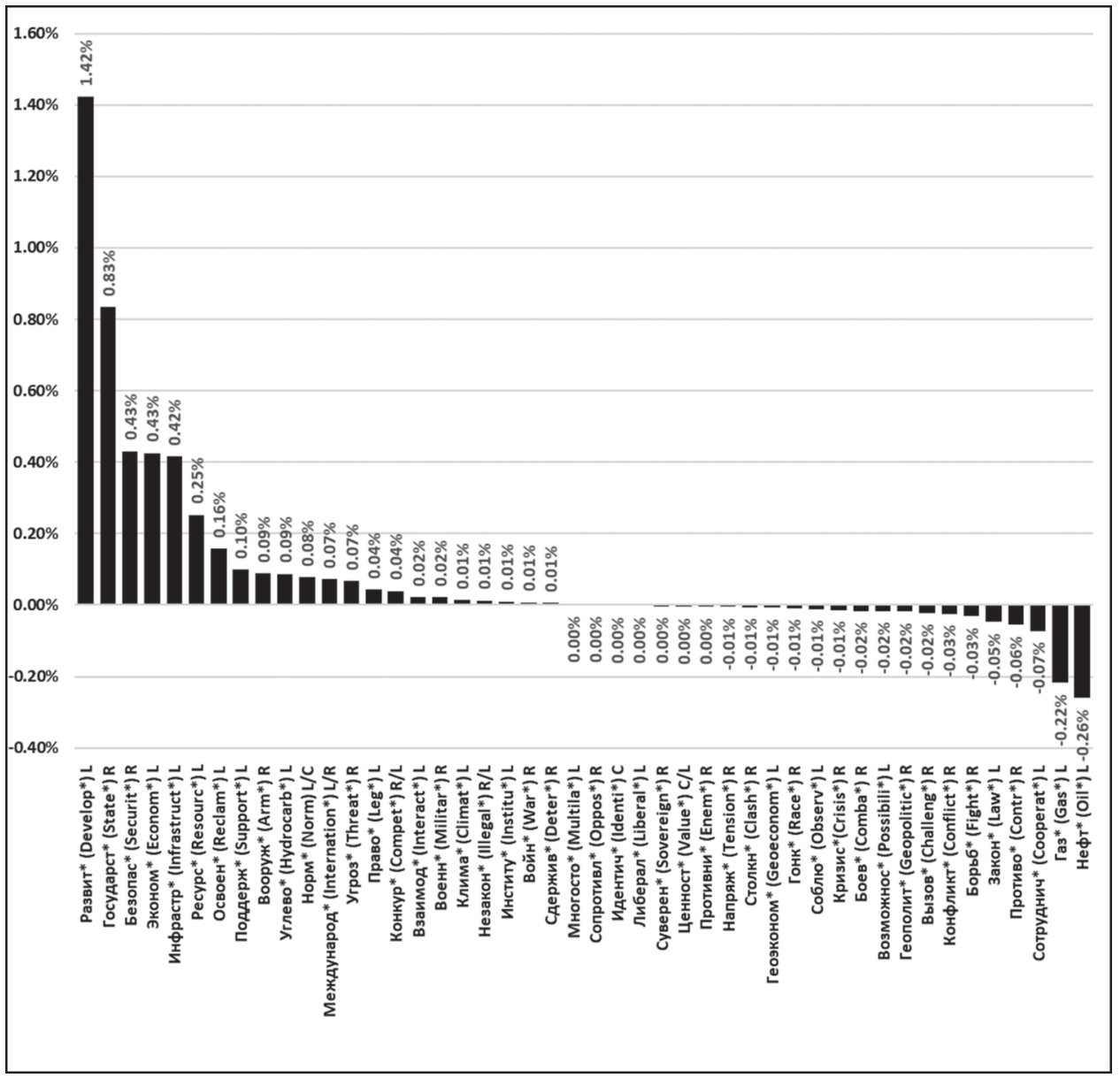

Figure 1. Word frequencies: comparing the 2013 Arctic Strategy with the 2013 RIAC anthology.

What are the main differences in topical and paradigmatic foci between Russian policymakers and the expert community? Comparison of the pre-2014 expert narrative with post-conflict 2019 Putin and Lavrov speeches (Figures 2 and 3) offers some interesting clues. Putin seems to pay much more attention to the question of Arctic development than does the Russian expert community; he appears more interested in infrastructure development, cooperation, and reclamation of the Arctic, and also speaks more frequently about institutions, economic aspects of cooperation (including gas projects), legal matters, and security and military issues. Foreign Minister Lavrov seems to share this interest in Arctic development, cooperation, and economic aspects, but compared to Putin (and the experts), his narrative is distinguished by more emphasis on geopolitical issues, potential conflicts, as well as climate-related challenges. 


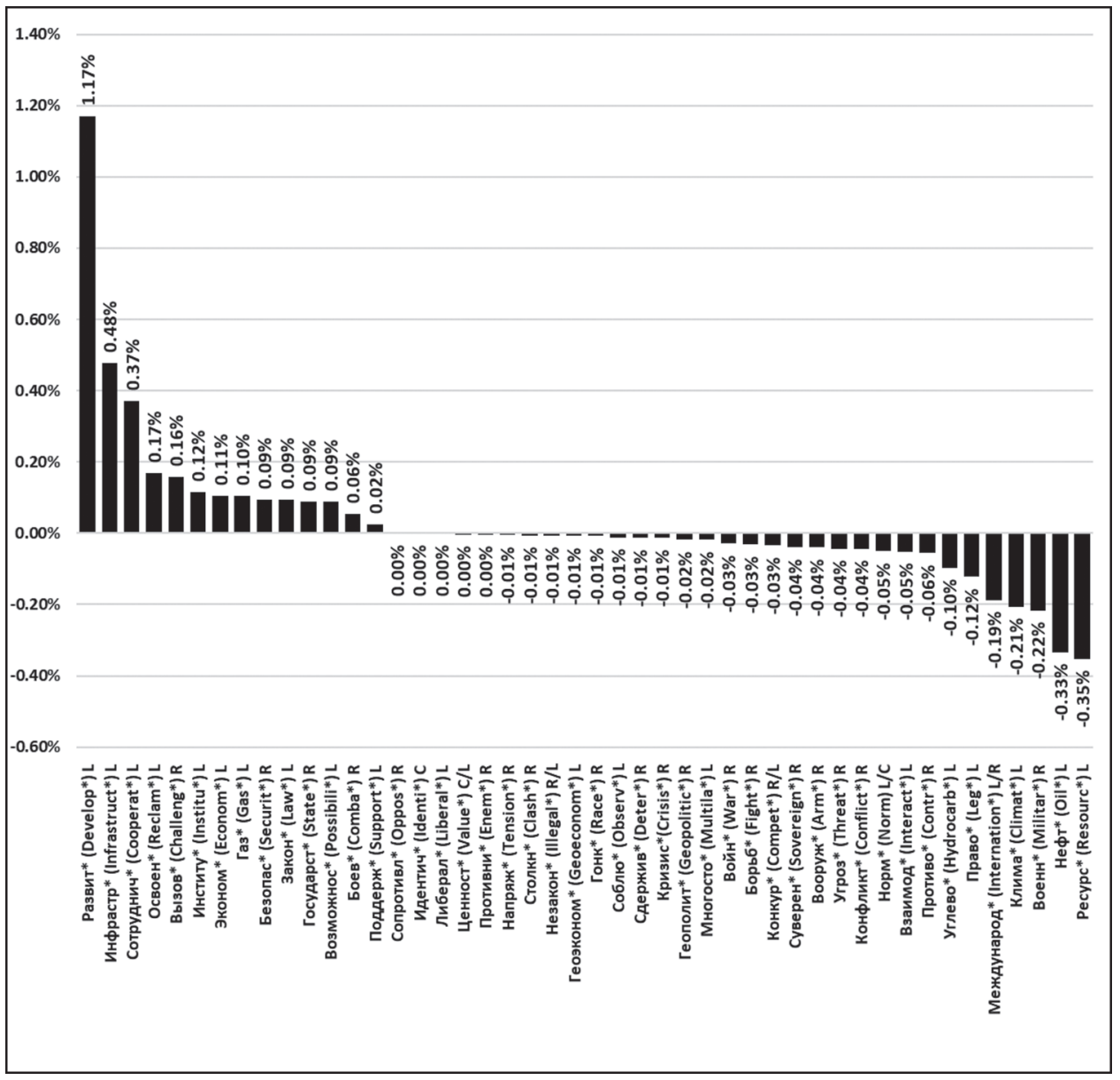

Figure 2. Word frequencies: comparing Putin's 2019 Arctic speech with the 2013 RIAC anthology.

As for changes in the official narrative on the Arctic, a comparison of Putin's speech with the 2013 Arctic Strategy shows that Putin is more interested in cooperation, energy-related issues, and addressing Arctic challenges than is evident in the Arctic Strategy. Again we find overlaps between Lavrov and Putin-as in their focus on cooperation and the energy sector-but Lavrov seems more preoccupied with the potential for conflict and the role of international cooperation and interaction in the Arctic - as well as with climate-related issues - than Putin or the Arctic Strategy.

Conversely, some topics are downplayed in the 2019 speeches compared to the 2013 Arctic Strategy. Terms associated with state activity, resources and security appear less frequently in the 2019 speeches than in the Arctic Strategy. This may imply that Putin and Lavrov now wish to underline possible positive Arctic synergies, with development of the region through greater international cooperation, 


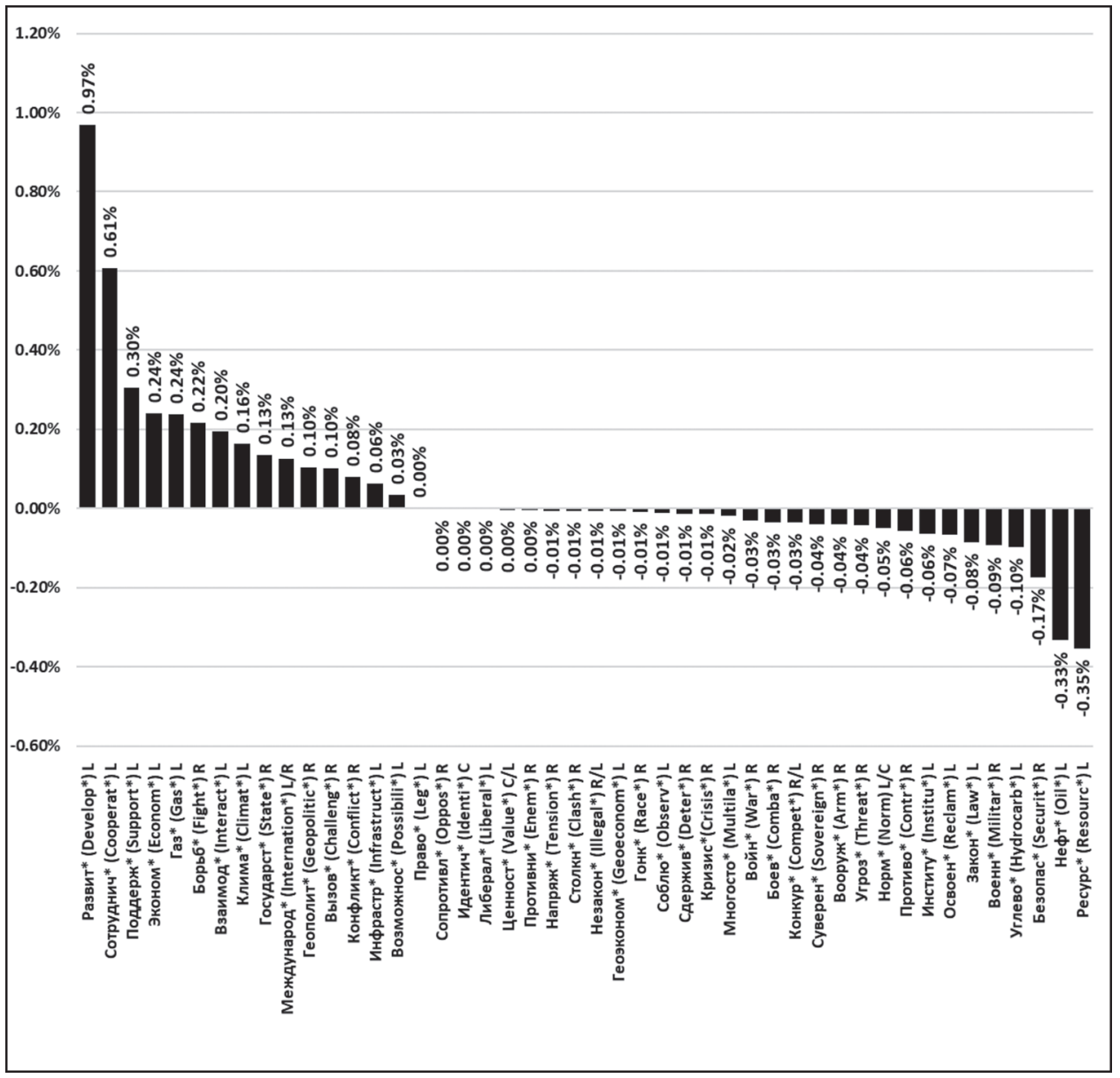

Figure 3. Word frequencies: comparing Lavrov's 2019 Arctic speech with the 2013 RIAC anthology.

including joint gas projects. However, comparison of word frequencies in Putin's and Lavrov's speeches reveals some interesting differences: Putin talks more about infrastructure and security-related aspects, whereas Lavrov pays far more attention to climate-related questions, international interaction, and cooperation. This could be seen as Putin presenting a more "neorealist" and Lavrov a more "neoliberal" narrative-in turn confirming the centrality of these two paradigmatic approaches to the Arctic in Russian official narrative.

\section{Concluding discussion}

A recent assessment of Russian Arctic policy by the Agency for Political and Economic Communications (APEK) would seem to support some of the conclusions drawn from our examination of Russian expert and official Arctic narratives. ${ }^{69}$ The 


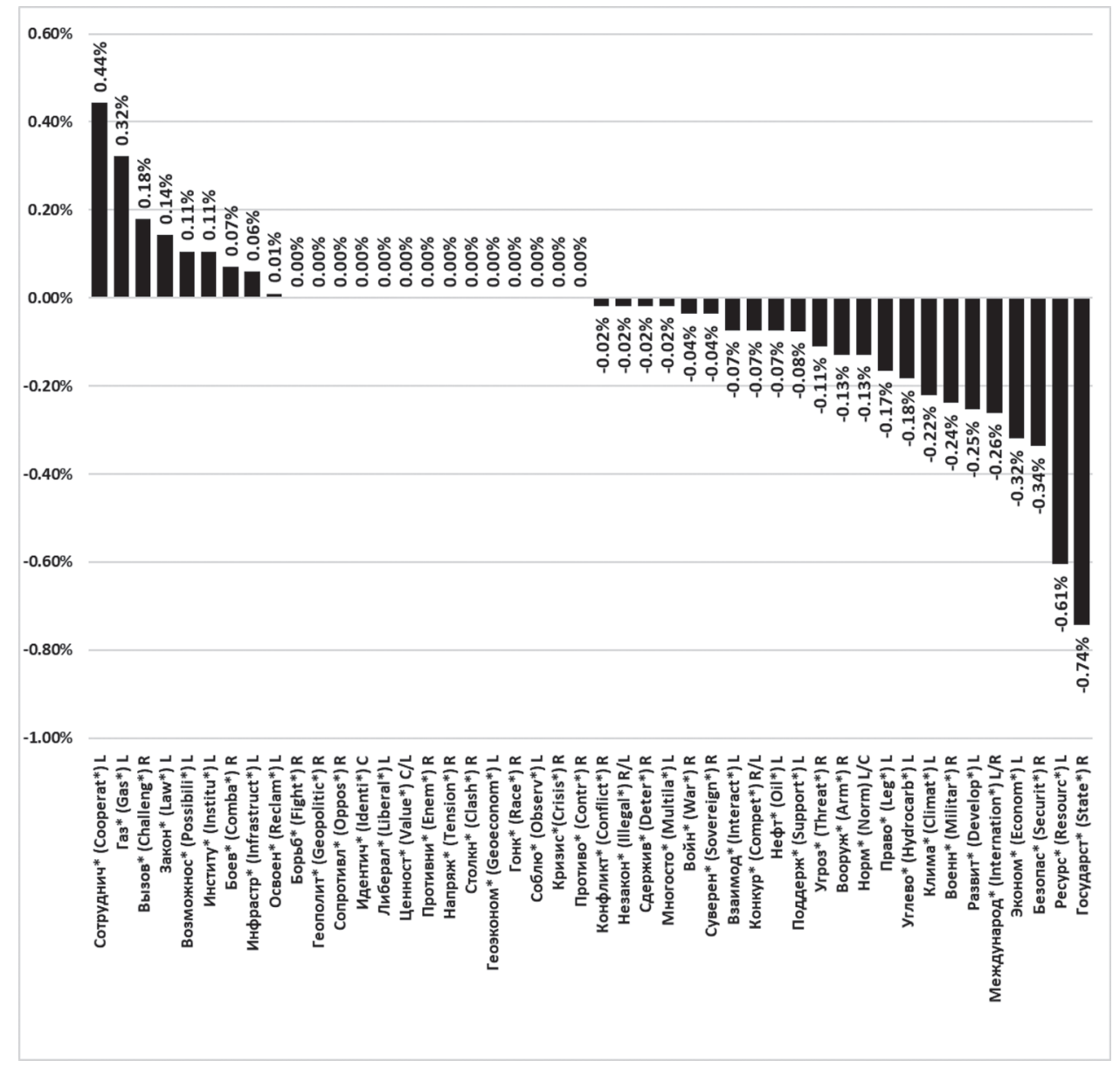

Figure 4. Word frequencies: comparing Putin's 2019 Arctic speech with the 2013 Arctic Strategy.

assessment lists the most successful projects realized in the Russian Arctic so farprojects important not only in infrastructural and economic terms, but which also have strategic and security significance. Some of the projects listed also involve foreign actors, adding a neoliberal flavor. For instance, the development of the LNG plant and port terminal on the Yamal Peninsula has been an international cooperative undertaking involving Russian, French, Japanese, and Chinese actors, underscoring the continued relevance of cooperative, neoliberal approaches to common Arctic and global challenges.

Russia's Arctic coastline is 24,140 kilometres long. ${ }^{70}$ In military-security terms, the most crucial is the Western part of the Arctic, between the Novaya Zemlya archipelago and the Kola Peninsula, where Russia's main naval strategic assets and access routes are located. Most of Russia's known natural resources, like the gas deposits on the 


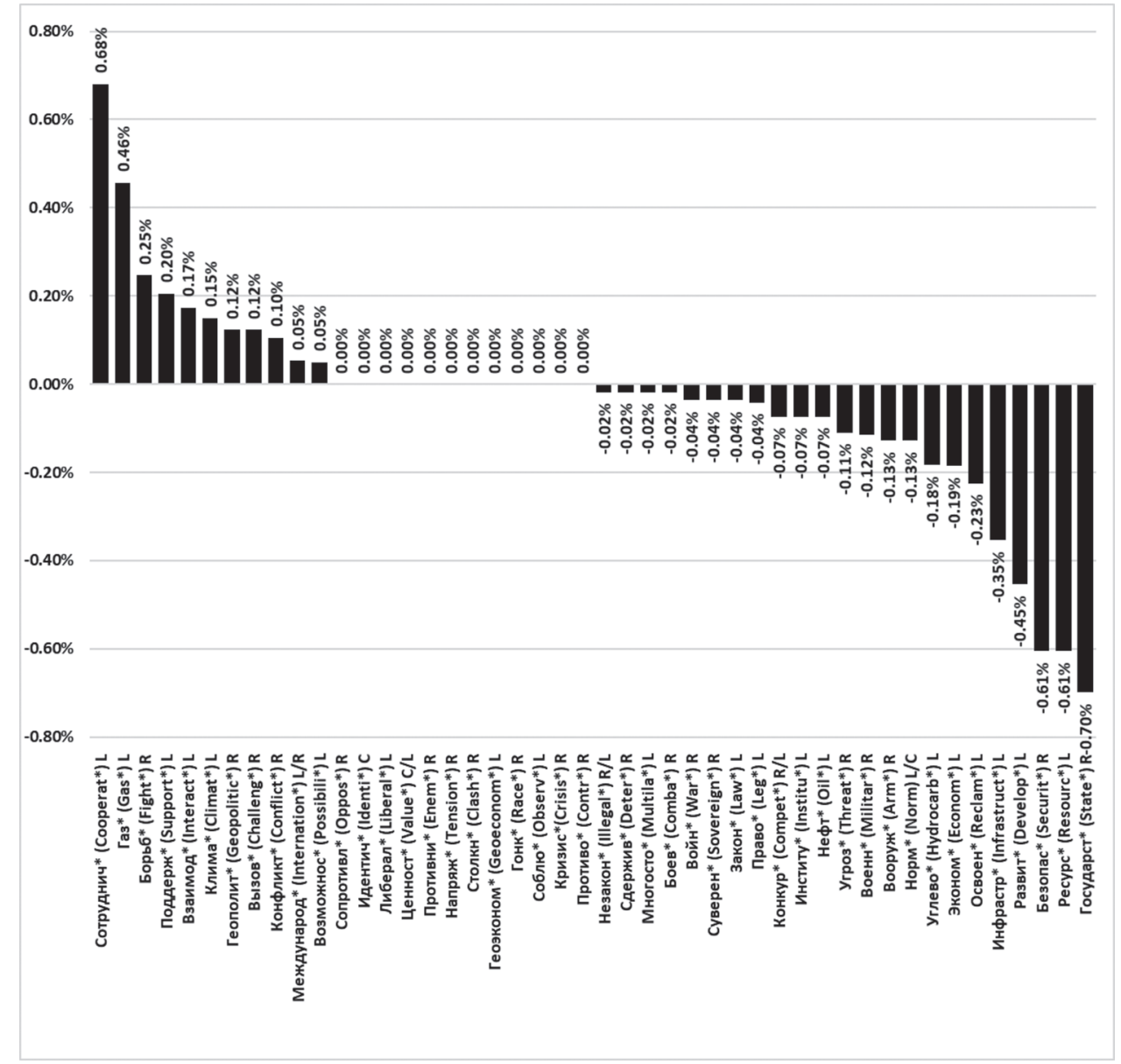

Figure 5. Word frequencies: comparing Lavrov's 2019 Arctic speech with the 2013 Arctic Strategy.

Yamal Peninsula, and metal deposits in the Norilsk area-and potentially resources that as yet are unmapped-are located in other parts of the Russian Arctic, regions weakly connected with the rest of Russia and with global markets. There is thus an urgent need to develop infrastructure that can secure access to these economic assets: but due to geographical and climatic conditions, development of such infrastructure is costly and entails various technological, economic and market-related risks. Risk-sharing as a means of reducing exposure to potential problems is a well-established practice in Russia; when the oil giant Rosneft, for example, went offshore, it offloaded most of the exploration and economic risks onto foreign partners. ${ }^{71}$

Our examination of Russian Arctic narratives reveals that a similar pragmatic approach that balances benefits and risks, has been adopted by Russian experts and policymakers in dealing with Russia's Arctic challenges. Indeed, these pragmatic 
ideas seem to inform not only Russian narratives but also Russian practices in the region. Policymakers may have realized that Russia, due to economic, structural and geographical constraints, will need to invite other actors to take part in development of the Arctic, security risks notwithstanding. There is a growing realization that Russia may be too weak to bear the whole burden of Arctic development on its own. However, Russia is strong enough to protect its strategic interests in the Arctic, even if external actors are allowed to take part.

The study of Russian Arctic narratives seems to confirm that the Russian policymaking community is trying to strike a narrative balance between neorealist and neoliberal approaches. We find: 1) relatively high continuity in Russian expert and official Arctic narratives; 2) relatively low impact of the 2014 crisis on the content of Russian expert and official "Arctic talk"; 3) dominance of neorealist and neoliberal understandings of international relations in expert and official narratives, and 4) continuity in how these pragmatic ideas have been translated into actual policymaking, also in the post-2014 context.

\section{NOTES}

1. Research for this article was made possible through a grant from the Research Council of Norway for the project "Can co-operative Russian and Western Arctic policies survive the current crisis in Russian-Western relations?" (CANARCT) (project no. 257638) and from the Russian Foundation for Basic Research (RFBR) for a project on Russia's soft security discourse on the Arctic (project no. 20-514-22001).

2. On this see, e.g., Anne-Marie Brady, China as a Polar Great Power (Cambridge: Cambridge University Press, 2017) or Christopher Weidacher Hsiung and Tom Røseth. "The Arctic Dimension in Sino-Russian Relations" in Sino-Russian Relations in the $21^{\text {st }}$ Century, Jo Inge Bekkevold and Bobo Lo, eds. (Cham: Springer International, 2019), 167-187.

3. Njord Wegge and Kathrin Keil, "Between Classical and Critical Geopolitics in a Changing Arctic," Polar Geography, 41, no. 2 (2018): 87-106.

4. Merje Kuus, "Critical Geopolitics," in The International Studies Encyclopedia, Robert A. Denemark, ed. (Oxford: Blackwell, 2010), 683-701.

5. Adriana Craciun, "The Scramble for the Arctic," Interventions, 11, no. 1 (2009): 103-114; Erik Ansink, "The Arctic Scramble: Introducing Claims in a Contest Model," European Fournal of Political Economy, 27, no. 4 (2011): 693-707; Klaus Dodds and Mark Nuttall, The Scramble for the Poles: The Geopolitics of the Arctic and Antarctic (Cambridge: Polity, 2015); Robert Legvold, "Russia-US: Confrontation in the Arctic Expanses?" Valdai Club, September 11, 2015. http://valdaiclub.com/a/highlights/russia-us-confrontation-in-the-arctic-expanses/.

6. Elana Wilson Rowe, "A Dangerous Space? Unpacking State and Media Discourses on the Arctic," Polar Geography, 36, no. 3 (2013): 232-244; Rebecca Pincus and Saleem H. Ali, "Have You Been to 'the Arctic'? Frame Theory and the Role of Media Coverage in Shaping Arctic Discourse," Polar Geography, 39, no. 2 (2016): 83-97.

7. Kuus, "Critical Geopolitics."

8. Vicki Squire, "Reshaping Critical Geopolitics? The Materialist Challenge," Review of International Studies, 41, no. 1 (2015): 139-159. 
9. "Arctic" is here understood in geographical and political terms - as the area north of the Arctic Circle, and as an area where the members of the Arctic Council pursue what they define in policy documents as their Arctic goals.

10. See Gearoid Ó Tuathail, "Understanding Critical Geopolitics: Geopolitics and Risk Society," Fournal of Strategic Studies, 22, no. 2-3 (1999): 107-124.

11. Gearóid Ó Tuathail and John Agnew, "Geopolitics and Discourse: Practical Geopolitical Reasoning in American Foreign Policy," Political Geography, 11 (2) (1992): 190-204.

12. Pavel Baev. "Russia's Ambivalent Status-Quo/Revisionist Policies in the Arctic," Arctic Review, 9 (2018): 408-424. See also Alexander Sergunin and Valery Konyshev, "Forging Russia's Arctic Strategy: Actors and Decision-making," The Polar fournal, 9, no. 1 (2019): 75-93.

13. For a good overview of the academic debates on international relations see Stephanie Lawson, Theories of International Relations: Contending Approaches to World Politics (Cambridge: Polity, 2015); Ken Booth and Toni Erskine, eds., International Relations Theory Today (Cambridge: Polity, 2016); Robert H. Jackson and Georg Sørensen, Introduction to International Relations: Theories and Approaches (Oxford: Oxford University Press, 2016).

14. Igor Ivanov, ed., Arkticheskii region: problemy mezhdunarodnogo sotrudnichestva (Moscow: Aspekt Press, 2013).

15. Carolina Vendil Pallin and Susanne Oxenstierna, Russian Think Tanks and Soft Power (Stockholm: FOI, 2017), p. 23.

16. Assigning concepts to various paradigmatic schools can be challenging. However, the different schools within IR use distinctive language and operate with certain key assumptions and concepts to describe how states relate to each other: these key concepts can be ascribed to various understandings of IR. See Joseph M. Grieco, "The Schools of Thought Problem in International Relations," International Studies Review, 21, no. 3 (2018): 424-46.

17. Kenneth N. Waltz, Theory of International Politics (New York: Random House, 1979).

18. John J. Mearsheimer, "Strategies of Survival," in Perspectives on World Politics, Richard Little and Michael Smith, eds. (London: Routledge, 2006), 69-79.

19. Vladislav Goldin, "Arktika v mezhdunarodnykh otnosheniyakh i geopolitike v XX - nachale XXI veka: vekhi istorii i sovremennost", Vestnik Severnogo (Arkticheskogo) Federal'nogo Universiteta. Seriya: Gumanitarnye i Sotsial'nye Nauki, no. 2 (2011): 22-34; Pavel Gudev, "Arkticheskaya politika Rossii: starye oshibki i novye vozmozhnosti," Mir i Politika, no. 1 (2013).

20. Petr Belov, "Resursno-demograficheskie aspekty rossiiskoi arkticheskoi geopolitiki," Geopolitika: Teoriya, istoriya, praktika, no. 1 (2012): 230-235; Lev Voronkov, "Interesy Rossii v Arktike," RSMD, August 30, 2012 https://russiancouncil.ru/analytics-and-comments/analytics/ interesy-rossii-v-arktike/.

21. Alexander Oreshenkov, "Arctic Diplomacy," Russia in Global Affairs, no. 4 (2009). https:// eng.globalaffairs.ru/number/n_14250; Aleksandr Ovlashenko and Ivan Pokrovskii, "Perspektivy pravovogo rezhima morskoi transportnoi sredy rossiiskoi Arktiki: Dualizm podhodov ili ikh eklektizm? Transportnoe pravo, no. 1 (2012): 12-20.

22. Goldin, "Arktika"; Voronkov, "Interesy".

23. Ibid.

24. "Arktika—goryachaya tochka XXI veka," Komsomolskaya pravda, April 23, 2007; Aleksei Fenenko, "Mezhdunarodnoe sopernichestvo za osvoenie obshikh prostranstv," Mezdunarodnye protsessy, 8, no. 1 (2010): 14-30.

25. Fenenko, "Mezhdunarodnoe"; Yurii Sinchuk and Valerii Zhuravel', "NATO contra Rossiya," Geopolitika i bezopasnost, no. 3 (2017): 113-120;Valerii Zhuravel', "Rossiiskaya armiya, MChS i Rosgvardiya v Arktike: voprosy bezopasnosti i mezhdunarodnogo sotrudnichestva," Nauchno-analiticheskii Vestnik IE RAN, no. 5 (2018): 158-164. 
26. Andrei Zagorski, Nestrategicheskie voprosy bezopasnosti $i$ sotrudnichestva v Arktike. (Moscow: IMEMO, 2016); Elena Chernenko, "Kholodnaya voina minovala Arktiku: Krizis v otnosheniyakh ne meshaet sotrudnichestvu RF i SShA v Zapolyar'e," Kommersant, May 10, 2017; Daryana Maksimova, "Arktika v 2035 godu: Ot konfrontatsii k sotrudnichestvu," RIAC, September 1, 2017. http://russiancouncil.ru/blogs/svfu-experts/33809/?sphrase_ id=19458405; Valerii Konyshev, Aleksandr Sergunin, and Lassi Kheininen, "'Globalnaya Arktika' kak region novogo tipa," in Asimmetrii regionalnykh integratsyonnykh proektov XXI veka, ed. Valery Mikhailenko (Ekaterinburg: Ural University Press, 2018), 412-27.

27. Vladimir Kudryavtsev, Yuridicheskii konflikt: sfery i mekhanizmy (Moscow: RAN, 1994); Anatolii Dmitriev, Konfliktologiya (Moscow: Gardariki, 2000); Marina Lebedeva, Mirovaya politika (Moscow: Aspekt Press, 2011).

28. Russian neoliberals focus on the areas of the Arctic that are still unregulated-not those that fall under the national jurisdiction of Russia or other Arctic littoral states.

29. Igor Leshukov, "Can the Northern Dimension Break the Vicious Circle of the RussiaEU Relations," in The Northern Dimension: Fuel for the EU? Hanna Ojanen, ed. (Helsinki: FIIA, 2001), 118-141; Andrei Zagorskii, ed. Arktika: Zona mira i sotrudnichestva (Moscow: IMEMO, 2011).

30. Vladimir Baranovsky, Russia's Attitudes Towards the EU: Political Aspects (Helsinki/Berlin: FIIA/IEP, 2002); Leshukov, "Can the Northern;" Zagorskii, Arktika.

31. See for instance Zagorskii, Arktika; Andrei Zagorskii, Aleksandr Glubokov, and Ekaterina Khmeleva, Mezhdunarodnoe sotrudnichestvo v Arktike: Doklad 2013 (Moscow: RSMD, 2013), http://russiancouncil.ru/common/upload/Arctic_Report_Rus.pdf; Andreii Zagorskii, Nestrategicheskie voprosy bezopasnosti $i$ sotrudnichestva $v$ Arktike (Moscow: IMEMO, 2016).

32. Zagorskii, Arktika; Zagorskii, Glubokov, and Khmeleva, Mezhdunarodnoe.

33. Iver B. Neumann, "Foreign Policy in an Age of Globalization," in Theorizing Foreign Policy in a Globalized World, Gunther Hellmann, Knud Erik Jørgensen, and Werner Link, eds. (Basingstoke: Palgrave Macmillan, 2015), 45-57, at 51.

34. Renat Perelet, Anna Kukushkina, and Maksim Travnikov, "Problemy obespecheniya ekologicheskoi bezopasnosti i upravlyaemosti v Arktike (ekonomiko-pravovye aspekty), in Rossiiskii ezhegodnik mezdunarodnogo prava (St Petersburg: Rossiya-Neva, 2000), 153-169; David Dodin, Ustoichivoe razvitie Arktiki (problemy i perspektivy) (St Petersburg: Nauka, 2005); Nadezhda Kharlampieva and Mariya Lagutina, "Transnatsional'naya model' arkticheskogo upravleniya v XXI veke," Arktika i Sever, no. 3 (2011): 64-82; Natalia Vasilieva and Van Chen'sin, "Modernizatsiya kak poisk novoi identichnosti Rossii: Arkticheskaya Model'," Vestnik mezhdunarodnykh organizatsii, no. 3 (2011): 20-26.

35. Perelet, Kukushkina, and Travnikov, "Problemy obespecheniya;" Dodin, "Ustoichivoe razvitie;" Dmitrii Sivakov, "Rossiiskaya Arktika: Sposoby pravovoi zashchity," Problemy Severa i Arktiki Rossiiskoi Federatsii, no. 9 (2009).

36. Kharlampieva and Lagutina, "Transnatsional'naya model'."

37. Aleksandr Kovalev, Sovremennoe mezhdunarodnoe morskoe pravo i praktika ego primeneniya (Moscow: Nauchnaya kniga, 2003); Aleksandr Kovalev, "Mezdunarodno-pravovoi rezhim Arktiki i interesy Rossii," in Ivanov, Arkticheskii region, 25-41.

38. Aleksandr Vylegzhanin, "Pravovoi rezhim Arktiki," in Mezhdunarodnoe morskoe pravo, Sergei Gureev, ed. (Moscow: Yuridicheskaya Literatura, 2003), 210-226; Anton Vasiliev, "Mezhdunarodnoe sotrudnichestvo v Arktike i podkhody Rossii," in Ivanov, Arkticheskii region, 94-103.

39. Lassi Heininen, Alexander Sergunin, and Gleb Yarovoy, Russian Strategies in the Arctic: Avoiding a New Cold War (Moscow:Valdai Club, 2014); Alexander Sergunin and Valery Konyshev, Russia in the Arctic: Hard or Soft Power? (Stuttgart: Ibidem-Verlag, 2016); Valery Konyshev, 
Alexander Sergunin, and Sergei Subbotin, "Russia's Arctic Strategies in the Context of the Ukrainian Crisis," The Polar fournal, 7, no. 1 (2017): 104-124.

40. Ole Wæver "Figures of International Thought: Introducing Persons Instead of Paradigms," in The Future of International Relations: Masters in the Making? Iver B. Neumann and Ole Wæver, eds. (London: Routledge, 1997), 17-21.

41. Aleksandr Dregailo andViktor Ulyanovskii, “'Nordman': Prolegomeny k sotsial'no-kul'turnoi tipologii severnogo cheloveka," Arktika i Sever, no. 1 (2011): 14-35; Mariya Nazukina, "Osnovnye trendy pozitsionirovaniya regionov rossiiskoi Arktiki," Labirint, no. 5 (2013): $59-68$.

42. Sergei Medvedev, "Zapovednaya territoriya: Arktiku nuzhno spasti ot korporatzii i gosudarstv, Forbes, October 3, 2013; Mariya Morgunova, "Retsentsiya: Arkticheskaya 'Saga' Rossii,” RSMD, May 7, 2014. http://russiancouncil.ru/library/library_rsmd/ russia-s-arctic-strategies-and-the-future-of-the-far-north/.

43. Medvedev, "Zapovednaya territoriya."

44. Ibid.

45. Tuathail, "Understanding Critical Geopolitics," 113.

46. For a good overview of the literature on various aspects of cooperation and conflict in the Arctic, see Mikkel Runge Olesen, "Cooperation or Conflict in the Arctic: A Literature Review,” DIIS Working Paper (Copenhagen: DIIS, 2014).

47. On various phases in Russian policy towards the Arctic see for instance Aleksandr Tamitskii, "Gosudarstvennaya politika sovremennoi Rossii v Arktike: etapy, prioritety i nekotorye itogi," Arktika i Sever, no. 6 (2012): 1-8.

48. See, for instance, Helge Blakkisrud and Geir Hønneland. Tackling Space: Federal Politics and the Russian North. (Lanham, MD: University Press of America, 2006), Yuri Lukin, Rossiiskaya Arktika v izmenyayushemsya mire (Arkhangelsk: IPTs SAFU, 2013), 132-139.

49. "Osnovy gosudarstvennoi politiki Rossiiskoi Federatsii v Arktike," June 14, 2001. http:// www.sci.aha.ru/econ/A111c.htm.

50. "Osnovy gosudarstvennoi politiki Rossiiskoi Federatsii v Arktike na period do 2020 goda i dal'neishuyu perspektivu," September 18, 2008. https://rg.ru/2009/03/30/arktikaosnovy-dok.html.

51. "Strategiya natsional'noi bezopasnosti Rossiiskoi Federatsii do 2020 goda," May 13, 2009. http://kremlin.ru/supplement/424.

52. "Strategiya razvitiya Arkticheskoi zony Rossiiskoi Federatsii i obespecheniya natsional'noi bezopasnosti na period do 2020 goda," February 20, 2013. https://bit.ly/2LUUw9U.

53. Ibid.

54. "Sotsial'no-ekonomicheskoe razvitie Arkticheskoi zony Rossiiskoi Federatsii na period do 2020 goda," April 21, 2014. http://government.ru/media/files/AtEYgOHutVc.pdf.

55. "Sotsial'no-ekonomicheskoe razvitie Arkticheskoi zony Rossiiskoi Federatsii," August 31, 2017. http://static.government.ru/media/files/GGu3GTtv8bvV8gZxSEAS1R7XmzloK6ar. pdf.

56. "Voennaya doktrina Rossiiskoi Federatsii," December 25, 2014. https://rg.ru/2014/12/30/ doktrina-dok.html.

57. “Morskaya doktrina Rossiiskoi Federatsii,” July 26, 2015. https://bit.ly/2M8JNFG.

58. RIA Novosti, "V Peterburge spushchen na vodu samyi moshchnyi v mire atomnyi ledokol 'Arktika',” June 16, 2016. https://ria.ru/atomtec/20160616/1448605334.html.

59. Vladislav Bukin, “Il'ya Muromets'-novyi ledokol-snabzhenets s nemetskimi kornyami," Korabel.ru, June 14, 2016. https://bit.ly/2ib20bI.

60. “Strategiya natsional'noi bezopasnosti Rossiiskoi Federatsii," December 31, 2015. https:// rg.ru/2015/12/31/nac-bezopasnost-site-dok.html. 


\section{Fakub Godzimirski $\mathcal{G}$ Alexander Sergunin}

61. “Kontseptsiya vneshnei politiki Rossiiskoi Federatsii,” November 30, 2016. http://kremlin. $\mathrm{ru} / \mathrm{acts} / \mathrm{bank} / 41451$.

62. “Osnovy gosudarstvennoi politiki Rossiiskoi Federatsii v oblasti voenno-morskoi deyatel'nosti do 2030," July 20, 2017. http://kremlin.ru/acts/bank/42117.

63. Vladimir Kotlyar, "The Arctic: A Region of Peaceful Development or Conflicts?” International Affairs, 62, no. 4 (2016): 76-86; Sergunin, Konyshev, and Subbotin, "Russia's Arctic Strategies"; Jørgen Staun, "Russia's Strategy in the Arctic: Cooperation, Not Confrontation," Polar Record, 53, no. 3 (2017): 314-332; Pavel Devyatkin, "Russia's Arctic Strategy: Aimed at Conflict or Cooperation? (Part I)," The Arctic Institute, February 6, 2018. https:// www.thearcticinstitute.org/russias-arctic-strategy-aimed-conflict-cooperation-part-one.

64. See for instance "Rossiiskii professor obosnoval peredachu Arktiki pod mezhdunarodnoi kontrol'," Lenta.ru, October 4, 2013. https://lenta.ru/news/2013/10/04/medvedev on Putin's reaction to Sergei Medvedev's proposals for making the Arctic an area of international responsibility.

65. Marina A. Lebedeva, "International Relations Studies in the USSR/Russia: Is There a Russian National School of IR Studies?" Global Society, 18, no. 3 (2004): 263-278. See also Lincoln E. Flake, “Contextualizing and Disarming Russia's Arctic Security Posture," The Fournal of Slavic Military Studies, 30, no. 1 (2017): 17-29.

66. Sergunin and Konyshev, Russia in the Arctic, 39-40.

67. "Plenarnoe zasedanie Mezhdunarodnogo arkticheskogo foruma," April 9, 2019. http:// kremlin.ru/events/president/news/60250.

68. "Vystuplenie Ministra inostrannykh del Rossii S. V. Lavrova na XI Ministerskoi sessii Arkticheskogo soveta, g. Rovaniemi, 7 maya 2019 goda," May 7, 2019. http://www.mid.ru/ arkticeskij-sovet/-/asset_publisher/0vP3hQoCPRg5/content/id/3637699.

69. APEK, Razvitie Arkticheskoi zony Rossii $i$ osnovnye vyzovy dlya ego osvoyeniya (Moscow: APEK, 2018).

70. "Russia." https://www.thearcticinstitute.org/countries/russia/.

71. See Indra Øverland, Jakub M. Godzimirski, Lars Petter Lunden, and Daniel Fjærtoft, "Rosneft's Offshore Partnerships: The Re-Opening of the Russian Petroleum Frontier?" Polar Record, 49, no. 249 (2013): 140-153. 